\title{
The Evolution of Administrative Systems in Kuwait, Saudi Arabia, and Qatar: The Challenge of Implementing Market-Based Reforms
}

\begin{abstract}
The 70\% plunge in oil prices since the second half of 2014 poses serious challenges for the oil dependent states of Kuwait, Saudi Arabia and Qatar, and revives their interest in accelerating the implementation of market-based reforms such as outsourcing, privatization and public-private partnerships. This article challenges the assumption that these reforms offer a panacea for administrative change, and argues that while they might appear to be a solution to the growing fiscal constraints in the three Gulf states, considerable administrative, cultural, economic, and political barriers hinder their effective implementation. The conclusion reached is that western labels of marketbased reforms offer limited options for the three states in the absence of strong political will to make fundamental reforms that threaten to alter the state-society relations. It is suggested that further theorization of administrative change is required in cultural contexts, such as the Gulf region, where administration and society are intertwined, and where trying to minimize the role and size of the state, poses a direct threat to the political legitimacy of the ruling elites.
\end{abstract}

Key words: Market-based reforms, GCC countries, privatization, public-private partnerships (PPPs), state-society relations

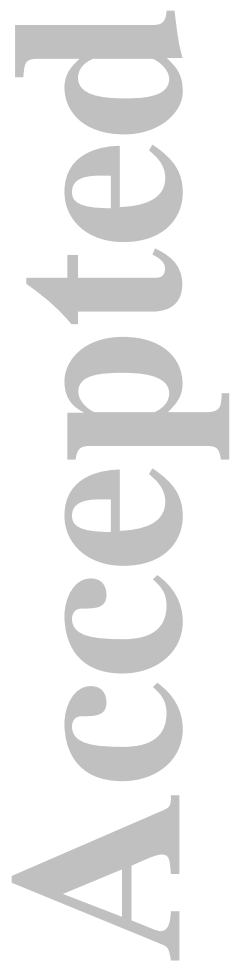

This is the author manuscript accepted for publication and has undergone full peer review but has not been through the copyediting, typesetting, pagination and proofreading process, which may lead to differences between this version and the Version record. Please cite this article as doi:10.1111/ dome.12093. 


\section{Introduction}

Public sector reform has been the subject of considerable debate over the past three decades. Fiscal pressures facing western governments in the 1980s, and the popularity of neoliberal ideology saw the introduction of market-based reforms such as downsizing the public sector, privatization, contracting out, and public private partnerships (PPPs) (Hammerschmid \& Angerer, 2005; Pollitt, 2015). While these initiatives have achieved mixed results, they did redefine the role of the state by decreasing the size and scope of the public sector, while trying to increase its effectiveness through the introduction of managerial practices designed to "run government as a business" and "do more with less" (Larbi, 2005:26) These reforms explain President Reagan's statement in 1981, that "government is not the solution to our problems; government is the problem." (McCourt, 2008: 468). Thus, a "smaller" and more efficient government that emulates the private sector's managerial techniques was perceived as a solution that western political leaders pragmatically embraced to tackle their growing budget deficits (Worthley \& Tsao, 1999; McCourt, 2008).

The transfer of ideas that have originated in western countries to the rest of the world, has been controversial. The diffusion of policy ideas "assumes receptive environments" (Heady, 2001; Common, 2012:13), but experience has shown that the transfer of western management techniques to non-western countries is "not impossible, but difficult" (Khodr \& Reiche, 2010:164). Christensen and Lagreid (2001) suggest that public sector reforms have varied results in different countries because of two key factors: 1) the "unique national political-administrative history, culture, traditions and style of governance..." and 2) the reform "actions taken by political and administrative leaders" (p. 75). Aristigueta \& Dooren (2007) argue that national contexts are "increasingly important for decisions, practices, and, finally, the results of reforms." (p. 464). Grossman (2012) points to governments readiness to embrace neoliberal ideas as a prerequisite for the success of reforms such as PPPs because introducing market-based reforms can considerably "alter the fundamental relationship between citizens and governments" (Blanchard, Hinnant \& Wong, 1998: 483). Hence, a careful examination of local contexts might help to determine the likelihood of public sector reforms achieving their objectives, especially in non-western countries (Hammerschmid \& Angerer, 2005).

In just fifty years, the Gulf Cooperation Council (GCC) states - comprising Bahrain, Oman, Kuwait, Qatar, Saudi Arabia and the United Arab Emirates - have built modern public and private sector institutions that took the western world many hundreds of years to establish. This progress was largely due to significant oil revenues accruing to the states' finances which enabled them to afford advice from international consulting firms, and to import human capital from other countries to construct bureaucratic machinery that parallels that seen in the western world (Khodr \& Reiche, 2010). Nonetheless, although their administrative structures resemble similar international institutions in form, closer examination reveals considerable differences in substance. Public sector institutions in the GCC region have mainly served the purpose of distributing largess to citizens in the form of lucrative government jobs, while the private sector has survived on the state's spending through rents and contracts that are generally granted to those with close links to the ruling families.

There is an urgent need to re-examine the sustainability of the current administrative practices, and the prospect of successfully introducing market-based reforms in the Gulf. In the past few decades, high oil prices provided little incentives for the Gulf states to reform their administrative systems, diversify their economies, or cut public spending (Common, 2008). Their response to past fluctuations in oil prices was to cut spending on infrastructure while keeping government salaries intact (The National, 2016). However, the increasing population growth and need for infrastructure development to stimulate economic growth means that Gulf states can no longer rely on old strategies to solve persisting fiscal challenges.

The plunge in oil prices by approximately $70 \%$ since mid-2014, and predictions that this could continue for the medium to long term, means that there is a pressing need for Gulf states to seriously consider reforming their public sectors, which consume a sizable portion of government spending (IMF, 2015a). Kuwait, Saudi Arabia and Qatar were selected for comparative analysis because despite sharing similar geographic, cultural and linguistic backgrounds, the sociopolitical factors that have shaped their administrative systems are markedly different. Accounting for these differences shows how different local factors can potentially derail policy reform tools. Moreover, the current low oil prices have produced Kuwait and Qatar's first major budget deficits in fifteen years, and have seen Saudi Arabia wrestling with a deficit of more than 20\% percent (The Economist, 2015a; The National, 2015).

Saudi Arabia is under particularly serious pressure to reform its bureaucracy and empower the private sector because of its much larger population (Table 1), and its increasing unemployment rate, which reached $30 \%$ among its youth in 2014 (World Bank, 2016). Furthermore, the International Monetary Fund (IMF) has warned that Saudi Arabia could drain its cash reserves in five years if it maintains its current spending while oil prices remain below 
\$50 a barrel (Egan, 2015). Additionally, the many billion dollars' worth of mega-infrastructure projects in the three states' pipelines, challenge the ability of these governments to finance them, especially Qatar, as it prepares for the 2022 FIFA World Cup under tight time and budget constraints (The Economist, 2015b).

\section{TABLE ONE HERE}

While an increasing body of literature on history and political economy analyze the state-society interrelations in the GCC region, little attention has been paid to the administrative apparatus through which these interactions take place (Jreisat, 2009; Common, 2008; Pollitt, 2015). There has been little scholarship that situates the GCC states within the international comparative public administration research agenda (Akoum, 2009; Khodr \& Reiche, 2010; Pollitt, 2015). The purpose of this article is to redress this paucity in the extant literature, and challenge the core assumption that market-based reforms form a panacea for administrative reform especially in Middle Eastern and Gulf countries (Polidano \& Hulme, 1999; Christensen, Lagreid, \& Roness, 2007). Scholars such as Osborne and Gaelber (1992) propose a "one size fits all" method for public management reform, and "describe a positivist management science approach that is believed to be applicable over time, place, and sector" (Aristigueta \& Dooren, 2007: 464). International consulting firms have embraced this approach in their work around the globe, with little attention paid to the impact of local contexts and cultures.

As a case in point, a recent McKinsey \& Company's report (2015) prescribes how the government of Saudi Arabia can reduce its reliance on oil, and achieve a "sustainable" economy by 2030. The Kingdom of Saudi Arabia's Vision 2030 (2016), which is championed by the Deputy Crown Prince Mohammed bin Salman, and aims to fully transform the Kingdom's economy from an oil based to market driven one by the year 2030, is built on the recommendations in this McKinsey report (Butler, 2016). The Vision 2030's proposed reforms include privatizing state owned enterprises (SOEs), minimizing state subsidies, and implementing western ideas such as private financing of large public infrastructure projects. This article argues that the McKinsey \& Company's report underappreciated the Kingdom's cultural and political economic characteristics, which raises doubts about both the efficacy of the proposed reforms, and their likely success. The practicality of these reforms needs to be evaluated within the modus operandi of the Gulf region's public and private sectors.

To achieve its objective, the article adopts a multidisciplinary approach by relying on works from history, political economy and public administration in order to form a comprehensive understanding of the challenges the three GCC states face to reform their public administration. This approach is important given the paucity of existing literature in the field of public administration and management in the region. The article begins by examining the impact of tribal and sociopolitical factors, the advent of the oil industry upon the evolution, and ties between the public and private sectors in the three Gulf states. This analysis helps our understanding of how administrative systems developed within the three Gulf states, and enables an appreciation of how these differ from the situation in western countries, from where most of the reform ideas have emanated. It is argued that while the implementation of market-based reforms in response to the fall of oil prices seems inevitable, administrative, cultural, economic, and political challenges hinder the practicality of these reforms within the three Gulf states.

It is outside the scope of this article to evaluate the performance of existing reforms, or offer alternative solutions (which both require separate research); nonetheless, analysis of the three states adds significantly to our knowledge regarding how historical bonds between state and society may constrain reform options. It illustrates how sociopolitical and economic factors, coupled with a local culture that resists administrative change, can form barriers to effective implementation of administrative change (Common, 2008; Khodr \& Reiche, 2010).

The conclusion reached is a rather pessimist one. The constraints that impede these reforms are deeply rooted in the sociopolitical foundations of the Gulf states' traditional tribal societies, which the modern state building process reinforced through its bureaucratic institutions. Reforming the current administrative practices will require a fundamental restructuring and redefinition of the public and private sectors' roles in the society upon which the political stability of these regimes is built and sustained. This article highlights the need for further theorization of administrative reform beyond the western prescriptions that currently dominate the public administration theory which, as this article demonstrates, do not offer practical options for the Gulf states.

Empirical sources informing this article are based on the first author's six years of researching and teaching within the Gulf states, which allowed direct contact and access to various senior government officials, businessmen, and academics. Such exposure provided a primary understanding of the dynamics that shape the public and private sectors and their impact on introducing administrative reforms in the region.

The following section examines the impact of sociopolitical and cultural factors, and the advent of oil wealth on the evolution of public and private sector institutions in the GCC region. This lays the foundation for a conceptual 
framework that guides the analysis of the three states, and reveals the different internal mechanisms that have interacted to produce three distinctive administrative systems. This analysis is followed by a discussion of the administrative, cultural, economic, and political barriers that obstruct market-based reforms in the three Gulf states. Countries with similar administrative and cultural heritage would do well to consider such factors before attempting to introduce market-based reforms.

\section{The Transition from Tribes to Modern States}

\section{The Impact of Tribal Tradition on the Sociopolitical History of the Gulf Region}

This section provides a brief analysis of the role sheikhs played in their tribal societies, and the persistence of traditional culture during the rapid transition to modern states. The state building process in the Gulf began as early as the seventeenth century, when members of prominent tribal families ascended to the sheikhdoms of their tribes. The sheikhdom system was characterized by connecting individual members of a tribe with unique "tribal sentiments" (Assabiya qabaliya) embodied in political loyalty to their sheikhs (Ibn Khaldun, 1377, 1981). From an anthropological perspective, the tribal structure signifies the existence of a cultural and social identity that is strictly based on local customs and preservation of tradition (al-Kandari \& al-Hadben, 2010; Makki, 2011).

Al-Naqib (1996) argues that the 'tribal structure' is not only a social phenomenon, but also a political system where mutual relations among few individuals, driven by group sentiments, determined the distribution of political authority in a hierarchical manner. Sheikhs derived their political legitimacy based on tribal origins, negotiations among the tribe's elderly notables and personal and leadership qualities such as courage and generosity (al-Jabri, 1982; Gause, 2000). Analyzing the evolution of modern Gulf states and their institutions, should take account of tribal tradition which unveils the unique sociopolitical features of the Gulf region, and avoids "reduce[ing] the question of political participation to a western spectrum of governance" (Segal, 2012: 128).

Given the small size of sheikhdoms, prior to the discovery of oil, the sheikhs played a central role in their societies. They were not simply political figures, but were regarded as the "figurative" fathers of their tribes (Peterson, 1992; Khodr \& Reiche, 2010) who were compelled, by the principles of Islam, to look after their tribes' wellbeing in all aspects (al-Jabri, 1982; al-Kandari \& al-Hadben, 2010). This is further illustrated by Sharabi (1998) who argues that the Arab political culture, especially in the Gulf region, is "neo-patriarchal" and the "central psychosocial feature ... is the dominance of the father (patriarch), the center around which the national as well as the natural family are organized. ... In both settings the paternal 'will' is the absolute 'will', mediated in both the society and the family by a forced consensus based on ritual and coercion" (p. 7).

To fulfill their "paternal" obligations, the sheikhs were expected to achieve justice and provide safety, unity, and protection against external threats in return for the financial tributes and political submission of their subjects (Peterson, 1977; Khodr \& Reiche, 2010). They were also directly accessible through the Majlis (Meeting Council), where they personally settled disputes and enforced decisions, and where they also received commoners to attend to their daily needs (Herb, 2009). The Majlis served as an informal and highly accessible, but nonetheless powerful, policy-making institution that, in modern terms, facilitated the sheikhdoms' "bureaucratic" functions (al-Rasheed, 2010). The ruler was required to consult with prominent members of the tribe within the Majlis regarding all decisions that affected the internal issues of their tribe, as well as their relations with neighboring tribes.

Critical to the sheikhs' political survival was their relationship with the traditional merchant classes that constituted the pillars of the "private sector" and signified the tribe's core economic resources, which often centered on the pearling industry and trade (al-Kuwari, 1978). They were the sheikh's source of financial support through the taxes and loans that were essential for buying weapons and paying the guards who protected the tribe from external threats (Crystal, 1995; Heard-Bey, 2005). This gave the traditional merchants an unequivocal bargaining position within the tribe that granted them unrestricted access to the sheikh's Majlis, in which they held advisory positions and contributed to the decision-making process. Moreover, relations of inter-marriage among prominent merchants and the sheikhs were common, and were a symbol of simultaneously solidifying and blurring the links between the political and economic components of the tribe (Ayubi, 1995).

Surviving within the tribal sociopolitical structure required the establishment and reinforcement of dense neopatrimonial and patronage practices to maintain the loyalty of all social strata both within and outside of the tribe to evade any potential coups (Kostiner \& Teitelbaum, 2000; Kamrava, 2007). To guarantee the loyalty and support of prominent families and latent rival tribes, sheikhs awarded gifts, money, favors or even established "blood ties" through marriage (Khuri, 1980). The stronger the neo-patrimonial base of the sheikhs, the longer their influence and the more stable their political regimes.

\section{The Discovery of Oil and Development of Public and Private Sector Institutions}


The advent of the petroleum industry in the 1950s resulted in a paradigm shift in the sheikhdoms' bargaining power. The modern state building process that began with the inflow of massive oil revenues directly to the "personal purse of the sheikhs," reinforced the ruling family's position in society from being a tribal alliance, to an "autocratic" regime that "constitutionally" positioned the sheikhs as members of a ruling family (al-Kuwari, 1978). Although petroleum revenues freed the sheikhs from dependence on the taxes garnered from their merchants and citizens, they also prompted questions regarding the legitimacy of the ruling families. Figure 1 outlines the Gulf's unique governance model in which the government is the key dominator over other sectors of society in a vertical manner. Since oil revenues flow directly into the coffers of the state, both the prominent merchant classes (private sector), and citizens (main holders of public sector jobs) subsist on the state's redistribution of these resources and depend on them for their wellbeing.

While bureaucratic institutions had existed for centuries in other Middle Eastern countries, formal public sector institutions in the Gulf were created during the 1950s and 1960s, with the flow of oil revenues to governments' coffers (Kamrava, 2011). Apart from providing services to the growing population, “...the bureaucracy serves as a respectable and modern-looking method of distributing part of [the oil] revenues. Unlike traditional straightforward cash handouts, bureaucracy provides a more dignified way of distributing largess", and access to powerful government officials in charge of contacts that bureaucrats could channel to their private businesses (Ayubi, 1990: 137). Furthermore, the highly influential political and bureaucratic positions in the Gulf states are commonly entrusted to members of the ruling families, or technocrats who express their allegiance to the rulers, as a strategy to solidify the latter's regimes against political rivals (Ayubi, 1995; Davis, Pitts, \& Cormier, 2000).

The roles of the private sector and civil society in Gulf state also show unique characteristics. The private sector whose activities revolve around construction, simple manufacturing, and food items is the domain that traditional merchant families occupy (Tétreault, 1995; Henieh, 2011). It has been predominantly built on kinship relations, and close links to the ruling family members helped these merchants get government contracts and other favors that supported the growth of their businesses (Rathmel \& Schulze, 2000; Crystal, 2014). The role of civil society in Saudi Arabia and Qatar is marginal. Political parties are forbidden (Freedom House, 2015), and the majority of existing non-government organizations (NGOs) are government funded, and their activities are highly monitored and restricted by their governments (CIA World Factbook, 2015). In Kuwait, however, the existence of the parliament allows some NGOs to lobby against government policies that affect the interests of Kuwaiti citizens but political parties are also banned in Kuwait.

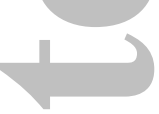

\section{FIGURE ONE HERE}

To summarize, the sociopolitical dynamics that characterize the tribal origins of the Gulf states, and the advent of oil, are two key factors that shaped the modern state building process. While modern public administration institutions were created, the traditional tribal forms have persisted, taking a modern form. Although the Majlis has lost most of its traditional value and is gradually replaced by state modern institutions, citizens' access to sheikhs, either through tribal leaders or influential merchants, often surpasses the power of formal institutions and guarantees a swift decision favorable to citizens' wishes (Mansour, 2008).

The next section analyzes how the tribal sociopolitical features and the advent of the petroleum industry shaped the development of the public and private sectors of Kuwait, Saudi Arabia and Qatar. Examining these countries through the presented theoretical framework is essential to understand their uniqueness and the factors that influence their administrative systems.

\section{Kuwait: A Political Space with Conflicting Interests Stalls Economic Growth}

The state-building process in Kuwait began in the eighteenth century, when al-Sabah was collectively selected by the Bani Utbah merchant families to lead and unify their emerging Sheikhdom of Kuwait (al-Sabah, 1980). While the al-Sabah family managed to establish themselves as the political leaders of a relatively conflict-free sheikhdom, the merchant class constituted the backbone of its economy (al-Kuwari, 1978; al-Kandari \& al-Hadben, 2010). They paid tax duties to al-Sabah to run the sheikhdom's administrative matters, recruited most of his subjects, and lent him money on multiple occasions (Crystal, 1995). The vital economic role played by the merchants allowed them to challenge and hold tight control over the reins of al-Sabah's political ambitions, which were constrained by their financial dependence on merchants. The discovery of oil in late 1930s freed the sheikh from the merchants' control, but at the same time triggered merchants' fear that Kuwait's natural resources would only be exploited by the alSabah family (al-Sabah, 1980; al-Kuwari, 1978). As a result, the merchants united to create an "institutionalized" form of political resistance, and established the Legislative Council in 1938, along with other institutions such as the 
Chamber of Commerce, in order to publicly confront the political powers of the ruler of Kuwait (Tétreault, 1995; Moore, 2004).

The independence of Kuwait from being a British protectorate in 1961 marked the beginning of a state-building process rife with political opposition. The merchants' enthusiasm to curtail the political powers of the sheikh and involve citizens in decision-making culminated in the formation of the first constitution and parliament in the Gulf in 1962 (al-Sabah, 1980; Ghabra, 1993; Smith, 1999). Although the Emir of Kuwait holds the right to appoint the prime minister, who then assembles the cabinet, the parliament still has significant powers including legislating, opposing legislation, or even dismissing the government (Louer, 2013).

The creation of a bureaucratic apparatus in Kuwait evolved in parallel with escalating petroleum revenues since the late 1930s (Ayubi, 1990; Crystal, 1995). Although the majority of senior government posts are mostly restricted to members of the ruling family and individuals with influential tribal origins, government policies and laws, such as Law No. 16/1960 were enacted to ensure that "jobs were made available in the government sector and public administration in particular, to every Kuwaiti looking for work" (al-Enzi, 2002: 887). To encourage government entities to recruit Kuwaitis, a special "Complementary Fund Budget" was created to support government entities to recruit Kuwaitis (al-Enzi, 2002). The Emir of Kuwait in 1979 admitted that " 64,000 civil servants were redundant, but for social reasons it was not feasible to dismiss them" (Nonneman, 1988: 31). Despite the IMF's (2015b) recommendations to "contain" the number of Kuwaitis in the public sector, some MPs are proposing legislation to cap foreigners' employment in the public sector at $20 \%$, and to amend labor laws to stipulate that Kuwaitis who apply for a government job must be offered one within six months. Otherwise, these applicants should be eligible for a full salary until their recruitment is finalized (Kuwait Times, 2014).

The state of Kuwait's use of public sector institutions as a largess distributive arm has detrimental effects on their performance. Kuwaitis formed $86.6 \%$ of total public sector employees in 2015 (Table 1), with salaries and benefits that increased by an estimated 540\% between 2001 and 2011 (al-Qabas, 2011, quoted in al-Zumai, 2013). The spending on public sector salaries consumed $50 \%$ of government spending in the 2014 budget, and $20 \%$ of the national GDP (IMF 2015a), which is "unmatched" by spending allocations of any developed or developing countries outside the Gulf (al-Monitor, 2014). The impact of employing Kuwaitis in the public sector regardless of their skills or competence has been one of the reasons for the public sector's inefficiency (al-Enzi, 2002). The overall quality and performance of government departments have been deteriorating according to the World Bank and other international organisations indicators in the past ten years.

Kuwaiti rulers have historically used the private sector to guarantee the traditional merchant class their share of oil wealth through government contracts and policies that protect them against foreign investment competition (Smith, 1999; Moore, 2002). This unwritten agreement has resulted in what Crystal (1995) calls the "ruler-merchant pact", by which the merchants give up their political activism in return for guaranteed access to the state revenues that took many forms. For example, the government bought pieces of lands for inflated prices from traditional merchant elites, and re-sold them to others at a meager price (Farah, 1989). Another example is al Sabah's (1980) observation regarding the increase in the number of public-private share holding companies that exceeded 50 between the 1950s and 1970s, which demonstrates the private sector capital development through direct government cash handouts.

Moreover, laws such as the Commercial Companies Law No. 15/1960, stipulated that any foreign business operating in Kuwait required a Kuwaiti partner who was entitled to $51 \%$ of the company. For decades, this law allowed local business families a direct monopoly over the private sector development for decades (Moore, 2004). Despite introducing the new Companies Law No. 97/2013 which abolished the local partner requirement, international businesses are still required to have a local agent who receives an annual fee for simply using their nationality to guarantee the foreigners businesses (al-Monitor, 2014).

The state, rather than the private sector, dominates the key activities of the local economy. As Table 1 illustrates, petroleum revenues constituted $89 \%$ of total revenues, and the $94 \%$ of export earnings in 2015 (Forbes, 2015a). The private sector's contribution to GDP was less than $31.5 \%$ in 2013, and in 2015, it employed $6 \%$ of Kuwaitis (IMF, 2014; Kuwait's Central Statistical Bureau, 2015). The private sector focuses mostly on industries that the public sector shows no interest in such as transportation, logistics, manufacturing and banking. Although it benefits from state subsidies of energy prices, the private sector largely employs expatriates (over 90\%) and pays insignificant taxes to the government (Table 1). The lines of the private sector are blurred by the dominance of SOEs, particularly in the lucrative petroleum related industries as they have a monopoly over those industries, and target the recruitment of Kuwaitis (Sartawi, 2012).

Kuwait's highly inefficient public sector and the political crisis that persisted for the past few decades that resulted in repeated dismissal of the parliament, are two key factors behind this country's weak economic performance (al-Monitor, 2014). In 2015, the Global Competitiveness Report indicated that the most problematic 
factor for doing business in Kuwait, was the "inefficient government bureaucracy" due to duplication and overstaffing of growing government entities by unmotivated and unskilled public servants (WEF, 2015). This situation not only fosters red tape, but also creates opportunities for corruption and abuse of government posts. Furthermore, the parliament has been repeatedly blamed by the business community for inhibiting economic growth in Kuwait as it "blocks most initiatives put forward by the government for fear that the benefits will go disproportionately, and unfairly, to the traditional economic class" (Herb, 2014: 143), and therefore its members inevitably vote for the government to spend the oil revenues on the creation of more public sector jobs and more lavish welfare allowances.

Between 2006 and 2011, the Emir dissolved the parliament five times, and called for fresh elections, affecting the economic policies proposed by the government with each dissolution (BBC, 2012). This challenging business environment has resulted in the suspension or cancellation of various large-scale-projects, and even led to some Kuwaiti businessmen investing their capital in other GCC states, such as the UAE and Qatar (al-Ghanim, 2010; Kinninmont, 2012; Herb, 2014). Although the July 2013 elections saw finally the emergence of a pro-government policies' parliament, prominent political commentators in Kuwait still have little confidence or hope for major economic and political reforms to take place (al-Monitor, 2014).

\section{Saudi Arabia: Fragmented Government Bureaucracy and Elite Dominated Private Sector}

Unlike Kuwait, in which al-Sabah was peacefully appointed as a sheikh with the consent of prominent tribal families, the modern Kingdom of Saudi Arabia is a result of intense internal tribal wars supported by traditional merchants loyal to al-Saud. These tribal wars took place from 1902 until the conquest of Riyadh in 1927 (Gray, 2014). The unification of the two major tribes of Nejd and Hijaz led to the birth of the Kingdom of Saudi Arabia in 1932 (al-Rasheed, 2010). The financial support of traditional Hejazi merchants through taxes and loans was critical in enabling al-Saud to afford the weaponry and resources necessary to fulfill his political ambitions, along with the backing of his tribesmen (Field, 1985).

While the parliament restricted the powers of the Emir of Kuwait and his involvement in the political and economic spheres, the al-Saud family received ideological backing from the Wahhabis, who had legitimized the family's political interests since 1744, and protected them from organized political opposition. This support was in return for implementing Abd al-Wahhab's strict orthodox teachings as the religious basis of al-Saud's Sheikhdom (al-Rasheed, 2010; Makki, 2011; Kamrava, 2011). Discovery of oil enabled the inchoate tribal sheikhdom to expand into a self-sufficient monarchy in which the al-Saud family members function as a "ruling institution," exploiting tribal values and origins to establish ".... a dominant elite of political and economic figures who operated their own patron-client networks" (Kostiner \& Teitelbaum, 2000: 137).

The role of the public sector in Saudi Arabia is not only to depoliticize citizens through highly paid government jobs — similar to Kuwait — but its institutions also serve to strengthen the historical ties among members of the ruling family and its supporters. The massive inflow of oil revenues in 1970s, did not just create a massive "flabby" machine of bureaucracy, but used its institutions to reinforce patrimonial and patronage ties among the members of the ruling family, the Wahhabi elite and influential tribal leaders (Ali, 2009; Pierce, 2012; Grey, 2014). In the absence of a powerful political institution, similar to the parliament in Kuwait, to question the actions of al-Saud and support the middle classes' interests, the government in Saudi Arabia has become a "family corporation" (House, 2013) or "family run government (Dunford, 2013), where key tribal leaders and royal descents occupy key government and ministerial positions. As a consequence, Saudi Arabia's administrative system is highly personalized, and "informal structures of authority determine the actual importance of institutions", and not necessarily the role they serve in society (Champion, 2003; Hertog, 2010a: 49).

Similar to Kuwait, the Saudi public sector is the largest recruiter of Saudi nationals, and the dominance of alSaud royals in key government positions leads to a "fragmented" and dysfunctional bureaucratic system that motivates various forms of corruption (House, 2013). In 2014, the percentage of Saudis as share of total employment in the public sector was more than $90 \%$ (Table 1). Given that these jobs are usually filled based on kinship and connections, rather than merit, Saudi public sector employees are not incentivized to perform well, thus making the bureaucracy over-staffed, slow and very expensive. For example, the wage bill in Saudi rose to $27 \%$ of total government expenditure while only 25\% went to capital/investment spending in 2008 (Ramady, 2010).

Government entities are typically led by princes and individuals with varying degrees of informal authority, influence, and interests. This results in a bureaucratic system which is "fragmented," and the implementation of policies is not determined by their potential to serve the wellbeing of the public more than to foster the individualistic interests of certain individuals (Hertog, 2010a; Kamrava, 2011; Pierce, 2012). Hence, personal agendas and interest drive policy-making, and sometimes those of benefit to the public are blocked by "individual 
agencies [which] often dilute [their] implementation, and cast smaller vetoes on bylaws or other specific procedures" (Hertog, 2010a: 31).

The environment of favoritism and informality has created an entire segment of middle-men with strong ties to the Saudi bureaucracy (al-Hegelan \& Palmer, 1985). Foreign companies are forced to employ these middle-men to maneuver through the complexity of the bureaucratic machine and help them push paperwork to be processed faster for a fee. Their role can even be to secure state contracts for their clients by matching them with Saudi partners in order to qualify for bidding for government contracts (Field, 1985; Ali, 2010; Hertog, 2010b). This point is emphasized by The Economist (2014), which states that "the co-ordination between state bodies is often poor, and it is still necessary to have the right connections to negotiate official bureaucracy." The Economist (2014) also quoted Princess Reema al-Saud, who stated that, while approaching the Saudi bureaucracy "you are at the mercy of an individual on duty on that day because rules are never applied quite the same as they are stated." Moreover, some of these middle-men (called Mua'qqib in Arabic) have access to princes through their informal Majlis meetings and use their access to negotiate deals for ordinary citizens with no connections to merchants or royal members. They sometimes even manage to bypass altogether the formal channels of decision-making to secure loan approvals or land acquisitions for their clients (Abir, 1987; Champion, 2003; House, 2013).

The private sector in Saudi Arabia exhibits the significance of tribal origins that enable certain influential families to control important sectors in the economy such as construction (Henieh, 2011). Originally, the traditional tribal merchants of Hijaz were amongst the most affluent in the Kingdom - they had close ties with the King who wanted to "settle the nomadic tribes and make them economically dependent on the state" to guarantee their loyalty and political submission (Gause, 2000: 174). In contrast to Kuwait, which had a historically well-established merchant class, the oil booms of the 1970s produced a new business elite from Nejd that made its riches from government contracts which were channeled to them through their kin in the state bureaucracy, during the years of massive state spending on infrastructure development. (Luciani, 2005; Ali, 2010). The influence of Hijaz-based traditional merchants eroded with time, and paved the way for newer and more adaptable business classes (Field, 1985; Chaudhry, 1997).

The weight of these family businesses in the Saudi economy is still prevalent as "...names like Bin Laden, Olayan, Zamil, Mahfouze, and al-Rajhi dominate the service sector...[which] is led by construction and real estate both heavily dependent on oil revenues" (House, 2013: 165). These family businesses form a substantial portion of Saudi Arabia's private sector where they occupy $90 \%$ of the existing companies and their contribution to the national GDP, having escalated to $25 \%$ in 2012 (al-Jassim, 2012). The rest of the private sector is left for smaller investors, who "rely heavily on the connections and support of members of the ruling family" (Ali, 2009: 23). Similar to Kuwait, in order to protect the economic interests of Saudi businesses against foreign competitors, government policies have been formulated to give local businesses precedence in acquiring state contracts and projects (Hess, 1995). Furthermore, foreign investors require Saudi agents and partners, who do not necessarily need to contribute any financial capital to a project, or indeed any investment beyond the use of their signature on government documents, a service for which they are paid a fee. Since economic patronage is a means through which the Saudi ruling family reinforces its political power, vital economic decisions are taken by the King or other highly ranked officials, who take into consideration the interests of the Saudi merchant classes (Malik \& Niblock, 2005).

The Saudi economy is massively reliant on oil resources, which made up $80 \%$ of the share of total budget revenues and $90 \%$ of export earnings in 2015 (Forbes, 2015b). General government expenditure as a percentage of GDP exceeded $50 \%$ in 2014, and private sector's survival relies on government spending and contracts that generate growth. The pressure on government to create more jobs for Saudis and increase their salaries, has tripled the public expenditure since 2004 (House, 2013). Nevertheless, despite the growing unemployment among Saudi youth, the private sector's workforce consists of only $22 \%$ Saudis, and the remaining made of expatriates. Another layer of complexity in Saudi's economy is added by SOEs such as the Saudi Arabia Basic Industries Corporation (SABIC) and Saudi National Bank, which are listed on the Saudi stock exchange as part of the private sector (Luciani, 2005).

The Kuwaiti and Saudi private sectors display some common features, and also some major differences. They both subsist on state spending that drives economic growth, and key industries are monopolized by SOEs that operate within the private sector's territory. The dominance of traditional family businesses and the legislative preferential treatment that they receive restrict foreign access to local markets, and hence reduce the competitiveness of their economies. Both Kuwaiti and Saudi businesses complain about the ineffectiveness of their bureaucracies as a barrier to private sector growth. However, in contrast to Kuwait, royal family members in Saudi Arabia are actively involved in the private sector by collaborating and partnering with major businesses. While the royal family in Saudi Arabia steers economic policies to best serve the interests of its business elites, the Kuwaiti members of parliament advocate distribution of oil revenues to Kuwaiti citizens, rather than handing them to the private sector that provides little direct benefits to Kuwaitis. 


\section{Qatar: Both Public and Private Sectors Dominated by Royal Elites}

The development of Qatar from a small tribal sheikhdom to a modern state shares some similarities and differences with Kuwait and Saudi Arabia. The al-Thani family is considered the founder of Qatar. Sheikh Mohammed bin Thani expelled the Bahraini representative in 1866 and ruled over 18 tribes he united through marriages with their tribal heads, as well as strong neo-patrimonial and patronage systems that bought him their loyalty (al-Kuwari, 1978; Fromherz, 2012). The absence of an established hereditary arrangement made the members of Qatar's ruling family the most imminent source of potential threat to its political legitimacy. Qatar's first constitution of 1970, restricted the ruling of Qatar to the al-Thani family, but did not specify hereditary requirements. As a result, Qatar's brief history has witnessed intense rivalry over political power among different members of the al-Thani family, evidenced by frequent coups between 1972 and 1996 (Kamrava, 2013). This competition over power has considerably shaped the ties between the public and private sectors in Qatar.

The advent of abundant petroleum revenues in 1949 allowed Abdullah bin Qassim al-Thani to play a "patriarchal" role in Qatari society (al-Kuwari 1978). In the absence of formal institutions, he "personally granted oil concessions, personally received the oil income, and personally decided the distribution of wealth" (Rathmell \& Schulze, 2000: 56). To legitimize and reinforce his political supremacy and prevent potential coups by his family members, he distributed cash handouts to all al-Thani members and also to other tribal leaders (al-Kuwari, 1978). Qatar's independence from being a British protectorate in 1971 inaugurated the beginning of a centralized administrative development process.

The rapid inflow of petroleum revenues happened in parallel with an unprecedented influx of expatriates to Qatar, and an urgent need for public sector services (Bahry, 2013). These changes saw the creation of a "personalized" bureaucratic machine that awarded vital government positions to the trusted members of the alThani, as well as other prominent families such as al-Attiyas (Khodr \& Reiche, 2010; Fromherz, 2012). The intention behind this practice was to maintain regime stability through patron-client relationships that pay for the political loyalty of tribal leaders through influential and high paying public sector jobs. Qatar, therefore, is like "a corporation with the Sheikh as CEO" (Fromherz, 2012: 127) who initiates liberalization initiatives that aim to further centralize, rather than limit, his powers (Kamrava, 2007).

The Qatari ruling family's "monopoly" over state institutions has repercussions on the quality of its public sector institutions. Although Qatar's population is much smaller than Saudi Arabia and Kuwait, its bureaucracy is similarly inflated, with lack of coordination among its units. The division of government entities among different members of the ruling and tribal families creates "personal fiefdoms" that reflect the ambitions and personal interests of their leaders (Fromherz, 2012; Kamrava, 2012). The weakness of public administration is a fact explicitly admitted in the Qatar government's National Vision 2030 which concedes that "[the state] requires continuous improvements in the efficiency, transparency and accountability of government agencies" to foster economic growth (General Secretariat for Development Planning, 2008: iii).

In the absence of an independent merchant class in Qatar, the private sector is also predominantly run by the alThani and its closest merchant families. In contrast to Kuwait and Saudi Arabia, the ruling family members in Qatar were "merchants first and rulers second" (Crystal, 1995). The advent of petroleum revenues and establishment of formal economic institutions witnessed the distribution of economic benefits to key members of the ruling family. Possessing the appropriate connections was particularly rewarding during oil booms, which were times that saw extensive government expenditures in infrastructure building. Because of its small geographical size, land is extremely expensive in Qatar, and having access to the al-Thani family, who own substantial tracts of land in business districts, is a condition to acquire land (Moore, 2002).

Another advantage that the merchant families have within the private sector is gained from laws and legislation that give precedence to Qatari merchants over international investors and businesses. This is similar to the protective policies and legislation that Kuwait and Saudi Arabia introduced to favor the traditional merchants and prioritize their access to public sector contracts. Therefore, foreign investors are obliged to partner with a local merchant to strengthen their business position, and despite recent amendments in laws that offer $100 \%$ ownership to foreign businesses, it remains harder to implement in practice (Crystal, 2014). In return, the merchants receive a share of profits for simply aligning themselves with the foreign investors to win the contract. As Crystal (1995) observed, "[the] most successful merchants were those with sheikhs for partners ... Smaller merchants, with no palace ties, did not fare well” (p. 151). While Qatar markets itself as a business-friendly environment that aims to attract foreign direct investment, access to the local business market can only be achieved by having the right contacts and connections with key Qatari economic decision-makers (US State Department, 2015).

Since Qatar's economy is acutely reliant on oil and gas revenues, the state spending plays a considerable role in driving economic growth. As demonstrated in Table 1, oil experts as a percentage of earnings exceeded $90 \%$, and the percentage of oil revenue as a share of total budget revenue was 62\% in 2015 (Forbes, 2015c; IMF, 2015c). 
Similar to Kuwait and Saudi Arabia, the Qatari government considerably subsidizes energy prices for the private sector which continues to rely on government contracts. Qatari citizen's preference for government jobs ( $84 \%$ of these jobs are held by Qataris in 2012) and their lack of skills required for private sector jobs, make expatriates more desirable by the private sector despite the government's "Qatarization" policies that encourage more inclusion of Qataris in the private sector (Mansour, 2007). Furthermore, SOEs led by members of the royal family control approximately half of the banking and real estate sectors, and run the most strategic and highly profitable institutions that operate in the private sector's territory such as Qatar Petroleum, Qatar Investment Authority, and Industries Qatar (al-Kuwari, 2012; Kamrava, 2013).

Since ruling family members support each other through public funds and public policies that are usually geared towards their best interests and those of local merchants, the distinction between public and private funds is also problematic (Mansour, 2007). Al-Kuwari (2012) argues that despite the existence of government institutions that "formally" appear to separate the rulers' funds from those of the state, in practice, the lack of transparent budgets and financial reports, render these distinctions artificial. Even the appointment of the director of the Qatari Chamber of Commerce is determined by the ruler who invariably appoints an al-Thani family member. Since the business community is not able to elect its own leader to voice concerns to policy-makers, the Chamber of Commerce, in effect, acts more "as [a] government agency than an independent social association" (Moore, 2002: 49). This is in stark contrast to the active roles played by the chambers of commerce in Kuwait and Saudi Arabia.

To summarize, although the sheikhs have a firm grip on power in the Gulf states, the three case studies reveal a playground in which complex webs of different actors and institutions interplay, all trying to maximize their share of oil revenues and power. Each of these states has its unique contextual factors that necessitate localized strategies for administrative reform that avoid "the one size fits all" approach. For example, Kuwait exhibits the most scattered political space and lethargic bureaucracy that result from the conflicting interests of MPs, merchants, government officials and citizens. Saudi Arabia's dominance of Wahhabi ideology and fragmented government institutions that are occupied by competing princes with their "shields of power" and own agendas require reform strategies that differ from Kuwait (Common, 2012). In Qatar, the absence of any opposing political or religious ideologies means that resistance for administrative reform could potentially emanate from the ruling elites to protect their interests within the public and private sector institutions they occupy.

The common thread that these countries share is the fusion of the political, administrative and economic institutions. As demonstrated in the section about transition to modern states, and further explored in the three case studies, the sheikhs and the merchants had been united through mutual interests, and marriage bounds that connected them together. When the building of modern bureaucratic institutions began, the sheikhs strategically used the financial and institutional resources to revive their traditional "paternalistic" role in tribal society and, at the same time, to legitimize their political supremacy. Therefore, the dual dichotomies of public/private and politics/administration that constitute a fundamental assumption in the NPM movement are obviously inapplicable in the Gulf context. This is an observation that further supports the article's premise that market-based reforms might not find a fertile soil in the Gulf region.

What are the implications of politicizing the administrative systems, the persistence of the traditional tribal culture, and mixing of the public and private sectors on the prospects of market-based reforms? The next section enumerates the obstructs that hinder the practicality of administrative reforms in the three GCC states.

\section{Barriers Facing the Implementation of Market-Based Reforms}

\section{Inefficient Administrative and Institutional Systems}

The experiences of other developing and transitional countries have shown that lack of efficient administrative systems impedes the implementation of complex policies such as privatization, outsourcing or PPPs, and increases their likelihood to fail (Awortwi, 2004; Larbi, 2005). The success of these policies necessitates high levels of efficiency within the machinery of government (Pessoa, 2008), streamlined coordination and collaboration among government institutions, and qualified human capital to administer complex contractual arrangements, and technical skills in order to partner with the private sector (Jamali, 2004).

Yet, since tribal origins and connections rather than skills or qualifications, have been the key criteria for obtaining government jobs, the three Gulf states' bureaucracies are not staffed with citizens who possess the rudimentary academic or professional expertise to implement such reforms (Jabbra \& Dwivedi, 2005; Hafez, 2009). Furthermore, the duplication of government institutions in order to provide jobs for larger numbers of citizens increases red-tape and creates overlapping bureaucratic hurdles for market-based reforms to smoothly operate.

In order for market-based reforms to succeed, independent regulatory and legal institutional frameworks need to be in place, and their roles equally respected by public and private sector entities (Pongsiri, 2002). This situation 
protects the right of the government and private sectors in case of disputes on the one hand; on the other it enables fair access to market opportunities under the role of law (Brinkerhoff \& Brinkerhoff, 2011). However, the examination of the quality and institutional capacities of the three GCC states to implement such reforms reveals numerous challenges. The fusion of politics and administration constitutes a serious challenge for institutions to perform effectively in the Gulf. According to al-Ghanim (2010), "Because [political and regulatory] institutions possess less power than the regime, they are unable to initiate meaningful reforms" (p. 139). Nevertheless, the political elites have ensured the effectiveness of regulatory institutions related to the petroleum industry which forms the backbone of their economies (Kamrava, 2012; Grey, 2014).

The prevalence of favoritism, Wasta (connections) and neo-patrimonialism enable influential members of merchant classes and government officials to continue their reliance on different forms of corruption to secure government contracts and benefits (Ali, 2010). While this is not unique to the three Gulf states, the analysis provided in this article demonstrates the extent to which these practices are not an exception - as it is the case in other countries - but rather the norm. Patron-client relationships, and patronage, continue to form the building blocks of the sheikhs' political legitimacy, and administrative culture (Mansour, 2007). In a context that lacks professionalism and good ethics, the efficiency gains that market-based reforms aspire for can be compromised, and lead to more waste of government funds and mismanagement of resources (Jabbra \& Jabbra, 2005; Jreisat, 2009).

\section{Cultural Barriers}

As indicated in the introduction of this article, local culture and tradition play an instrumental role regarding the fate of administrative reforms (Christensen \& Lagreid, 2001). Since tribalism "is deeply rooted in economic, social, and political life" of GCC states, the role of culture is a crucial variable to consider while analyzing the prospect of market-based reforms that have a strong Anglo-Saxon cultural imprint (Ali, 2010: 26). This is particularly the case for a conservative and highly religious society such as Saudi Arabia, which often looks at experiences of China, Turkey and Malaysia as a proof for its reluctance to implement western-labeled ideas of administrative reform (Common, 2012).

Although GCC states have selectively implemented some managerial techniques that encourage higher results and outcomes, these reforms have not tackled the basic challenges related to the lack of transparency, accountability, corruption nor decentralization of decision making. Furthermore, efforts for reform are also undermined by cultural habits that are deeply rooted in the region's traditional society (Assad, 2002). Cultural traditions dictate that tribe, family, kin, and friends should be every individual's source of loyalty, and; therefore, institutions and "social organizations exist to further the particularistic interests of a collective group" rather than the public good of society at large (Bjerke \& al-Meer, 1993: 33). In a cultural setting where personal connections are considered a priority in deciding business deals rather than the quality of the services per se (al-Kazemi \& Ali, 2001; Assad, 2002), policies such as contracting out, and public-private partnerships that necessitate competitive, transparent and fair bidding processes might not find a solid ground in these three states. Evidence from international experiences shows that in the absence of clear mechanisms of transparency, role of law, control of corruption and accountability, market-based reforms might end up costing the government far more than if these services were delivered in the traditional manners (Klijn \& Teisman, 2003).

The local culture also sustains the "traditional command and control" methods and top-down decision-making that are associated with the "paternalistic" role of managers in the Gulf (Jreisat, 2009; Ali, 2010). Public sector employees are expected to strictly abide by the directions of their superiors and never question their authority or decisions (Ali, 1990; Jabbra \& Jabbra, 2005). This authoritarian form of bureaucracy forces public sector employees to abide by established rules and policies, and as a consequence, restricts risk taking and innovation which form a key component of modern administrative reform initiatives. On the other hand, it delays decisions, complicates processes, and creates an inundation of red-tape. Since market-based reforms are meant to streamline decisionmaking and deliver services through collaboration, partnerships, and private sector management methods, the rigidity of the bureaucratic systems could either delay and halt projects, or channel them towards individuals with access to decision-makers.

\section{Statist and Elitist Dominated Private Sectors}

The absence of liberal market economies in which competition drives economic growth within the private sector is another challenge that limits the potential of market-based reforms in the three Gulf states. The centralization of economic planning in the hands of the rulers who personally decide on key matters related to the future of the economy and investment strategies, undermines the formal role of economic institutions (al-Kuwari, 2012; House, 2013). Moreover, reliance of family businesses on governments' contracts which are determined by state spending and the fluctuation of international oil prices, also challenges the adoption of market-based reforms in 
times of fiscal crises. When oil prices are low, and state spending shrinks, private sector's growth declines in the absence of mature and strong local markets that can independently generate growth.

The traditional merchant families' dominance in the economies of Kuwait, Saudi Arabia and Qatar defy the assumptions underlying the private sector's competition- driven performance. Although family businesses occupy over $85 \%$ of privately held businesses in the Middle East (Deloitte, 2014), they lack transparent governance mechanisms and resist transforming into joint stock companies out of fear of losing control over their family heritage, or exposing data about their performance (PwC \& the Pearl Initiative, 2013). Since data about their profits, business models, internal capacity, or actual size in the local markets is scarce, it is difficult to determine their eligibility for government contracts on a competitive basis. More importantly, the governments of the three Gulf states cannot implement economic policies that could jeopardize the traditional family businesses because of their reliance on their political acquiescence for decades.

The private sectors in Kuwait, Saudi Arabia and Qatar also lack the needed talent, expertise and innovation that are key pillars for delivering value for money. Hence, restriction of foreign companies' entry into the private sector is another reason that limits the value of reforms such as PPPs or outsourcing. The formal (and informal) preferential treatment that traditional merchant families receive through governments' policies and legislation eliminate fair competition with foreign companies, and compromise the efficiency and quality of services the private sector should presumably deliver under market mechanisms.

Al-Turkey (2011) conducted a survey of 300 managers and supervisors in Saudi Arabia which found that 97\% of government mega-infrastructure projects were not completed on time, and more than $80 \%$ of them significantly exceeded their budgets. Local private sector contractors did not have strong incentives to deliver on time and under budget as good performance was not a criterion for their selection to deliver the projects in the first place. In this case, if privatized SOEs or PPP contracts are awarded in similar manners, these reform instruments will dramatically fail to achieve the desired outcomes. Moreover, powerful merchant families can always use their connections with the ruling families to lobby against government policies that contradict or threaten their interests.

\section{The Threat of Market-Based Reforms to the Sheikhs' Political Legitimacy}

Because market-based reforms such as privatization and downsizing are essentially intended to cut government jobs and reduce public spending, they form a direct threat to the political legitimacy of the sheikhs. Citizens of the three Gulf states could be the first targets of such policies since they are paid higher salaries - although sometimes less competitive than expatriates - and expect more benefits (Biygautane \& al-Yahya, 2014). As indicated earlier, citizens of the three Gulf states consider government jobs their share from oil revenues, and are very reluctant to join private sector jobs. Laying off Gulf citizens from public sector jobs or reducing the social benefits they have been entitled for during the past five decades, could shake citizens' political acquiesce which sheikhs have maintained through government jobs and social benefits. For example, when the Arab Spring events erupted, the Saudi King Abdullah, in fear that these events could reach Saudi Arabia, announced in March 2011 an unprecedented \$130 billion in spending ( $85 \%$ increase to the annual budget) to pay an extra two months' salaries to government employees, build 500,000 units of low income housing and create more public sector jobs (House, 2013). Similar generous initiatives were carried out by Kuwait and Qatar, in particular, the announcement of significant salary increases and creation of more public sector jobs for citizens (Stack, 2011).

Politically motivated policies such as 'nationalization of workforce' that oblige public and private sectors to meet certain quotas in hiring citizens regardless of their skills contradict the three governments' other policies to downsize the public sector, and undermine the effectiveness of market-based reforms. In 2014, Saudi Arabia refused to renew more than 9000 contracts for expatriates working in the public sector and restricted these jobs only to Saudis (Gulf Business, 2014). Kuwait's Central Statistical Bureau (2015) found that 58\% of unemployed Kuwaitis refuse joining private sector jobs and wait for the government to provide their constitutional right of a guaranteed job in the public sector. Qatar's Ministry of Administrative Development announced in December 2015 that Qatari citizens will be occupying more than $90 \%$ of public sector jobs within 10 years (Qatar News Agency, 2015). While such nationalization policies guarantee jobs to citizens, they compromise the quality of services when recruitment is based on nationality rather than qualifications and experience.

Although privatization has been in the three GCC states' agendas for the past three decades, few cases of successful privatization programs exist, and they are restricted to sectors that do not threaten citizens' jobs such as power and water desalination or telecommunication industries (Mansour, 2008; Akoum, 2009). In Kuwait, for instance, despite passing a privatization law in 2010 that provided the legal framework to privatize SOEs, the privatization program has been extremely sluggish (Sartawi, 2012). It has been severely opposed by the parliament which is concerned about corruption in selling government assets to traditional merchants, and especially the loss of Kuwaiti jobs when state enterprises are transferred to the private sector (Tétreault, 2000). Furthermore, Kuwait's 
privatization law stipulates that all Kuwaiti employees must keep their jobs with the same salaries when the public entity is transferred to the private sector for a minimum period of five years. It holds the state responsible for finding them a job if they are not willing to work in the privatized company (Sartawi, 2012). Similarly, the Kingdom of Saudi Arabia's Vision 2030 (2016) emphasizes the privatization of state's assets, but this has not yet been followed by any strategies or policies regarding the fate of redundant positions among Saudis in case of privatizing state owned assets. In Qatar, the government selectively privatized sectors and state enterprises with few numbers of Qataris to ensure that this policy does not affect the Qatarization scheme (Mansour, 2007). Such political involvement in privatization policies clearly defies the ideological and practical goals of privatization programs that aim to cut the number of redundant employees in privatized entities to drive efficiency and enhance performance.

\section{Conclusion}

The examination of the modern state building processes in Kuwait, Saudi Arabia and Qatar reveals the development of administrative systems that are deeply influenced by the traditional tribal culture of the region. The advent of the petroleum industries accelerated institutional building, which sheikhs used to legitimize their political supremacy and leadership. While this was an affordable strategy during the period of high oil prices, the massive drop in these prices since the second half of 2014, revives the need for reform. Increasing population growth necessities mega infrastructure projects, which these states can no longer finance. This article posits that implementing western models of market-based reforms in response to these fiscal deficits is constrained by a plethora of administrative, cultural, economic, and political factors. Addressing these constraints requires revisiting the fundamental roles of the public and private sectors in society, and this can threaten the political legitimacy of the ruling elites. This explains the hesitance of the three Gulf states to implement drastic policy reforms that could lead to a reduction in jobs for citizens and/or minimize access to government contracts that merchant families have traditionally enjoyed.

This article revealed how western reform prescriptions that dominate public administration literature offer only limited options for reform in political and social contexts similar to the Gulf states. Theorization of administrative reforms need to go beyond reform instruments that are based on western cultural and governance assumptions, and account for societies with traditional heritage and politicized administrative systems. This will form the beginning of a serious search for indigenous models of public sector reform that take account of the cultural and political realities of local administrative contexts.

Knowledge gained from this analysis provides instructive lessons, particularly, for countries with similar cultural and administrative systems. First, it demonstrates that complex market-based reforms such as privatization and PPPs might not deliver the levels of efficiency and effectiveness that their proponents assert in the absence of basic institutional and administrative prerequisites. In countries characterized by politicized administrative systems and complex bureaucracies, privatization and PPPs could open new windows of opportunities for powerful bureaucrats to utilize their sources and channel government contracts to their close relatives or friends.

Second, the three cases studies illustrate how local culture plays a considerable role in blocking administrative reforms. The capacity of institutions to regulate and monitor the transparency of outsourcing, privatization and PPPs can be undermined by a tradition and culture that prioritize loyalty to personal relationships, rather than to state institutions. In such cases, state institutions fail to guarantee that merit and competitiveness, rather than individual connections, will be the criterion for awarding government contracts. Furthermore, rigid bureaucratic systems often cause major delays that could potentially lead to cancellation of PPP projects or the transfer of government enterprises to the private sector. A hierarchical and top-down approach to management could defy the objectives of these reforms, including to streamline the processes of decision making and enable managers to innovate in delivering results and outcomes. Appreciating the role of culture is particularly important for foreign consultants seeking to implement western based reform programs.

Third, the prospect of successfully implementing PPPs is limited in societies where the state drives economic growth, or where certain elite families control key sectors of the economy. These two factors obstruct the competitive forces of the private sector that normally motivate companies to provide services with the highest possible quality while managing risks and minimizing costs. This is further undermined when local legislation and policies block or limit the entry of foreign businesses — who usually have higher levels of experience and knowhow - compared to the local markets.

Fourth, political will to reform the public sector was the driving force behind implementing market-based reforms and downsizing government in western countries. This article has shown that in the absence of such political will, especially with regards to reducing public sector jobs, western reforms can be implemented, but may be modified to such extent, that they are unable to achieve their purpose. For example, the privatization label has been used in Kuwait, Saudi Arabia and Qatar for decades, but with little success, since it was accompanied by laws 
and policies that protected the jobs of redundant citizens and kept their salaries intact. This situation is typically the case in societies where largess distribution and extended welfare systems are the tools political leaders use to secure the acquiescence of their citizens. Hence, when market-based reforms are adjusted to protect the sheikhs' social contracts with their citizens, implementation of administrative reforms will be a futile endeavor.

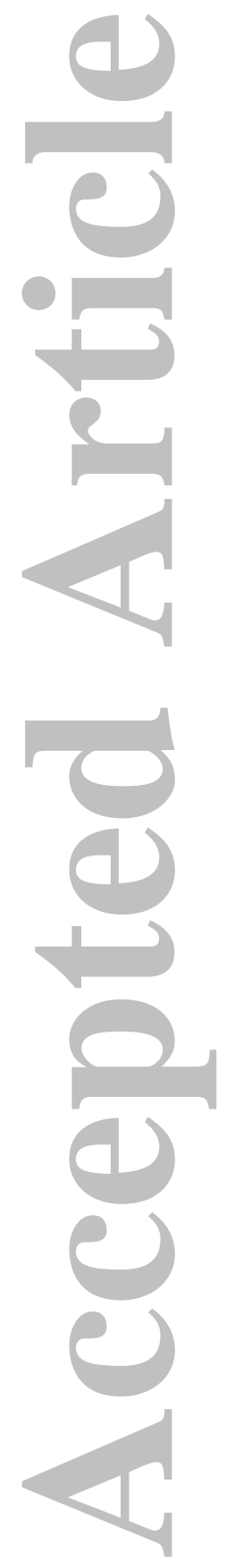




\section{References}

Abir, M. (1987). The consolidation of the ruling class and the new elites in Saudi Arabia. Middle Eastern Studies, 23(2), 150-171.

Akoum, I. (2009). Privatization in Saudi Arabia: Is slow beautiful? Thunderbird International Business Review, $51(5), 427-440$

al-Enzi, A. (2002). Kuwait's employment policy: Its formulation, implications, and challenges. International Journal of Public Administration, 25(7), 885-900.

al-Ghanim, M. (2010). Do elections lead to reform? Assessing the institutional limits of representative bodies in Bahrain, Kuwait and Saudi Arabia. Contemporary Arab Affairs, 3(2), 138-147.

al-Hegelan, A., \& Palmer, M. (1985). Bureaucracy and development in Saudi Arabia. Middle East Journal, 39(1), 48-68.

Ali, A. (2009). Business and management environemnt in Saudi Arabia: Challenges and opportunities for multinational corporations. London, UK: Routledge.

Ali, A. (2010). Managing MNC-government negotiations in Saudi Arabia: The key role of elites. Journal of promotion management, 16, 494-521.

al-Jabri, M. (1982). Fi al-khitab al-'arabi al-mu'asir [On contemporary Arab discourse] Beirut, LB: Dar al-tali'a. al-Jassim, D. (2012). Family businesses contribute 25\% of GDP. Arab News. Retrieved 16 May 2016 from http://www.arabnews.com/family-businesses-contribute-25-gdp\#

al-Kandari, Y., \& al-Hadben, I. (2010). Tribalism, sectarianism, and democracy in Kuwaiti culture. Digest of Middle

East Studies, 19(2), 268-285.

al-Kazemi, A., \& Ali, A. (2001). Managerial problems in Kuwait. International Journal of Management Development, 21(5), 366-375.

al-Kuwari, A. (1978). Oil revenues in the Gulf Emirates: patterns of allocation and impact on economic development. Essex, UK: Bowker.

al-Kuwari, A. (2012). The visions and strategies of the GCC countries from the perspective of reforms: the case of Qatar. Contemporary Arab Affairs, 5(1), 86-106.

al-Monitor. (2014). Public sector reform in Kuwait key to economic development. Retrieved 16 May 2016 from http://www.al-monitor.com/pulse/business/2014/09/kuwait-economic-growthreforms.html\#ixzz3yQPaL433

al-Naqib, K. (1996). The struggle between tribe and democracy London, UK: Dar al-Saqi.

al-Rasheed, M. (2010). A history of Saudi Arabia. Cambridge, UK: Cambridge University Press.

al-Sabah, Y. (1980). The oil economy of Kuwait. London: Kegan Paul International.

al-Turkey, T. (2011). The reality of projects in terms of organization and structure, and the reasons for success and failure In Saudi Arabia. Al-watan Newspaper (In Arabic). Retrieved 19 May 2016 from http://www.alwatan.com.sa/Local/News_Detail.aspx?ArticleID=49126\&CategoryID=5

al-Zumai, F. (2013). Kuwait's political impasse and rent-seeking behaviour: A call for institutional reform. Kuwait Programme on Development, Governance and Globalisation in the Gulf States. London, UK: London School of Economics and Political Sciences.

Aristigueta, M., \& Dooren, W. (2007). Toward a performing public sector-the roles of context, utalization, and networks. Public performance \& management review, 30(4), 463-468.

Assad, S. (2002). Sociological analysis of the administrative system in Saudi Arabia: In search of a culturally compatible model for reform. International Journal of Comparative Management, 12(3\&4), 51-83.

Ayubi, N. (1990). Arab bureaucracies: Expanding size, changing roles. In G. Luciani (Ed.), The Arab state (pp. 129149). London, UK: Routledge.

Ayubi, N. (1995). Over-stating the Arab state. London, UK: I.B. Tauris.

Awortwi, N. (2004). Getting the fundamentals wrong: woes of public-private partnerships in solid waste collection in three Ghanian cities. Public Administration and Development, 24, 213-224.

Bahry, L. (2013). Qatar: Democratic reforms and global status. In K. Abbas (Ed.), Governance in the Middle East and North Africa: A handbook. Hoboken, NJ: Taylor and Francis.

BBC. (2012). Kuwait Emir al-Sabah dissolves parliament. Retrieved 06 June 2016

from http://www.bbc.com/news/world-middle-east-19861587

Biygautane, M., \& Al-Yahya, K. (2014). Talent management in the Gulf region: Challenges and opportunities. In G. Dessler, \& A. al-Ariss (Eds), Global talent management - Challenges, strategies, and opportunities - Series management for professionals (pp. 197-215). Cham Zug, CH: Springer International. 
Bjerke, B., \& al-Ameer, R. (1993). Culture's consequences: management in Saudi Arabia, Leadership \& Organization Development Journal, 14(2), 30-35.

Blanchard, L., Hinnat, C., \& Wong, W. (1998). Market-based reforms in government: towards social subcontract. Administration and society, 30(5), 483-512.

Brinkerhoff, D., \& Brinkerhoff, J. (2011). Public-private partnerships: Perspectives on purposes, publicness and good governance. Public Administration and Development, 31, 2-14.

Butler, N. (2016). Saudi Arabia-the dangers of a fanciful vision. Financial Times, Retrieved 12 June 2016 from http://blogs.ft.com/nick-butler/2016/05/02/saudi-arabia-the-dangers-of-a-fanciful-vision/

Champion, D. (2003). The Paradoxical Kingdom: Saudi Arabia and the momentum of reform. London, UK: Hurst.

Chaudhry, K. (1997). The price of wealth: Economies and institutions in the Middle East. Ithaca, NY: Cornell University Press.

Christensen, T., \& Lagreid, P. (2001). New public management: the effects of contractualism and devolution on political control. Public Management Review, 3(1), 73-94.

Christensen, T., Lagreid, P., \& Roness, P. (2007). Organization theory and the public sector: Instrument, culture and myth, New York, NY: Routledge Taylor and Francis.

CIA World Factbook. (2015). Retrieved 22 April 2016 from https://www.cia.gov/library/publications/the-worldfactbook/geos/sa.html

Common, R. (2000). The East Asia region: Do public-private partnerships make sense? In S. Osborne (Ed.), Publicprivate partnership: theory and practice in international perspective (pp. 135-148). London, UK: Routledge.

Common, R. (2008). Administrative change in the Gulf: Modernization in Bahrain and Oman. International Review of Administrative Sciences, 74(2), 177-193.

Common, R. (2013). When policy diffusion does not lead to policy transfer: Explaining resistance to international learning in public management reform. In P. Caroll \& R. Common (Eds.), Policy transfer and learning in public policy and management: International contexts, content and development. New York. NY: Routledge.

Crystal, J. (1995). Oil and politics in the Gulf: Rulers and merchants in Kuwait and Qatar. Cambridge, UK: Cambridge University Press.

Crystal, J. (2014). Eastern Arabian States: Kuwait, Bahrain, Qatar, United Arab Emirates, and Oman. In M. Gasiorowski (Ed.), The government and politics of the Middle East and North Africa (7th ed., pp. 157-196). Boulder, CO: Westview Press.

Davis, J., Pitts, E., \& Cormier, K. (2000). Challenges facing family companies in the gulf region. Family Business Review, 13(3), 217-238.

Deloitte. (2014). Family-owned businesses make up the largest sector of the GCC economy. Retrieved 20 April 2016 from http://www2.deloitte.com/xe/en/pages/about-deloitte/articles/deloitte-family-owned-businessesmake-up-the-largest-sector-of-GCC-economy.html

Dunford, D. (2013). The Kingdom: Can the magic last? In K. Abbas (Ed.), Governance in the Middle East and North Africa: A handbook. Hoboken, NJ: Taylor and Francis.

Egan, M. (2015). Saudi Arabia to run out of cash in less than 5 years. Retrieved 20 May, 2016 from http://money.cnn.com/2015/10/25/investing/oil-prices-saudi-arabia-cash-opec-middle-east

Farah, T. (1989). Political culture and development in a reniter state: The case of Kuwait. Journal of Asian and African Studies, XXIV(1-2), 106-113.

Field, M. (1985). The merchants: The big business families of Saudi Arabia and the Gulf states. New York, NY: The Overlook Press.

Forbes. (2015a). Kuwait. Retrieved 18 May 2016 from http://www.forbes.com/places/kuwait/

Forbes. (2015b). Saudi Arabia. Retrieved 18 May 2016 from http://www.forbes.com/places/saudi-arabia/

Forbes. (2015c). Qatar. Retrieved 18 May 2016 from http://www.forbes.com/places/qatar/

Freedom House. (2015). Retrieved 16 May 2016 from https://freedomhouse.org/

Fromherz, A. (2012). Qatar: A modern history. London, UK: I.B.Tauris.

Gause, F. (2000). The persistence of monarchy in the Arabian Peninsula: A comparative analysis. In J. Kostiner (Ed.), Middle East monarchies: The challenge of modernity. London, UK: Lynne Rienner.

Ghabra, S. (1993). Kuwait: Elections and issues of democratization in a Middle Eastern state. Digest of Middle East Studies, 2(2), 1-27.

General Secretariat for Development Planning. (2008). Qatar National Vision 2030. Retrieved 16 May 2016 from http://www.gsdp.gov.qa/www1_docs/QNV2030_English_v2.pdf 
Gray, M. (2014). Global security watch: Saudi Arabia. Santa Barbara, CA: Praeger.

Grossman, S. (2012). The management and measurement of public-private partnerships: Toward an integral and balanced approach. Public performance \& management review, 35(4), 595-616.

Gulf Business. (2014). Saudi Arabia Replaces Public Sector Expat Workers. Retrieved 22 May 2016 from http://gulfbusiness.com/saudi-arabia-replaces-public-sector-expat-workers/\#.Vz33BpF97IU

Hafez, Z. (2009). The culture of rent, factionalism, and corruption: A political economy of rent in the Arab World. Contemporary Arab Affairs, 2(3), 458-480.

Hammerschmid, G., \& Angerer, D. J. (2005). Public-private partnership between euphoria and disillusionment: Recent experiences from Austria and implications for countries in transformation. Romanian journal of political sciences, 1, 129-159.

Heady, F. (2001). Public Administration: A comparative perspective (6th ed.). New York, NY: Marcel Dekker.

Heard-Bey, F. (2005). The United Arab Emirates: Statehood and nation-building in a traditional society. Middle East Journal, 59(3), 357-375.

Henieh, A. (2011). Capitalism and class in the Gulf Arab states. New York, NY: Palgrave Macmillan.

Herb, M. (2009). All in the family: Absolutism, revolution and democracy in the Middle Eastern monarchies. Albany, NY: The University of New York Press.

Herb, M. (2014). The wages of oil: Parliaments and economic development in Kuwait and the UAE. Ithaca, NY: Cornell University Press.

Hertog, S. (2010a). Princes, brokers and bureaucrats: Oil and the state in Saudi Arabia. Ithaca, NY: Cornell University Press.

Hertog, S. (2010b). The sociology of the Gulf rentier systems: Societies of intermidiaries Comparative studies in society and history, 52(2), 1-37.

Hess, A. (1995). Peace and political reform in the Gulf: the private sector. Journal of International Affairs, 49(1), $103-122$.

House, K. (2013). On Saudi Arabia: Its people, past, religion, fault lines-and future. New York, NY: Vintage

Ibn Khaldun, A. (1377, 1981). The Muqaddimah: An introduction to history Princeton, NJ: Princeton University Press.

IMF. (2014). Retrieved May 10, 2016 from: www.imf.org

IMF. (2015a). Saudi Arabia: IMF Country Report No. 15/251. Retrieved 16 May 2016 from https://www.imf.org/external/pubs/ft/scr/2015/cr15251.pdf

IMF. (2015b). Kuwait: IMF Country Report No. 15/327. Retrieved 16 May 2016

from https://www.imf.org/external/pubs/ft/scr/2015/cr15327.pdf

IMF. (2015c). Qatar: Selected issues. IMF Country Report No. 15/87. Retrieved 16 May 2016 from https://www.imf.org/external/pubs/ft/scr/2015/cr1587.pdf

Jabbra, J., \& Dwivedi, O. (2005). Administrative culture in a global context. Whitby, ON, CA: de Sitter.

Jabbra, J., \& Jabbra, N. (2005). Administrative culture in the Middle East: The case of the Arab World. In J. Jabbra \& O. Dwivedi (Eds.), Administrative culture in a global context (pp. 135-153). Whitby, ON, CA: de Sitter.

Jamali, D. (2004). A public-private partnership in the Lebanese telecommunications industry: critical success factors and policy lessons. Public Works Management Policy, 9(2), 103-119.

Jreisat, J. (2009). Administration, globalization, and the Arab states. Public organization review, 9, 37-50.

Kamrava, M. (2007). Royal factionalism and political liberalization in Qatar. The Middle East Journal, 63(3), 401420.

Kamrava, M. (2011). The modern Middle East: A political history since the first world war (2nd ed.). Los Angeles, CA: University of California Press.

Kamrava, M. (2012). The political economy of rentierism in the Persian Gulf. In M. Kamrava (Ed.), The political economy of the Persian Gulf. London, UK: Hurt.

Kamrava, M. (2013). Qatar: Small State, Big Politics. Ithaca: Cornell University Press.

Khodr, H., \& Reiche, D. (2010). The specialized cities of the Gulf Cooperation Council: A case study of a distinct type of policy innovation and diffusion. Digest of Middle East Studies, 21(1), 149-177.

Khuri, F. (1980). Tribe and state in Bahrain: The transformation of social and political authority in an Arab state. Chicago, IL: University of Chicago Press.

Kingdom of Saudi Arabia's Vision 2030. (2016). Retrieved 19 May 2016 from http://vision2030.gov.sa/en

Kinninmont, J. (2012). Kuwait Parliament: An Experiment in Semi-democracy. Retrieved 15 April, 2016 from https://www.chathamhouse.org/publications/papers/view/185357, Accessed:

Klijn, E. H., \& Teisman, G. R. (2003). Institutional and strategic barriers to public-private partnership: An analysis of Dutch cases. Public Money and Management, 23(3), 137-146. 
Kostiner, J., \& Teitelbaum, J. (2000). State-formation and the Saudi monarchy. In J. Kostiner (Ed.), Middle East monarchies: the challenge of modernity. London, UK: Lynne Reinner.

Kuwait's Central Statistical Bureau. (2015). Data retrieved 20 May 2016 from http://www.csb.gov.kw/Default_EN.aspx

Kuwait Times. (2014). MP calls to cut expats in public sector to $20 \%$-Govt, assembly agree on naturalizing 4,000 bdeoons. Retrieved 10 May 2016 from http://news.kuwaittimes.net/mp-calls-cut-expats-public-sector-20govt-assembly-agree-naturalizing-4000-bedoons/

Larbi, G. (2005). Applying the new public management in developing countries. In Y. Bangura \& G. Larbi (Eds.), Public sector reform in developing countries: Capacity challenges to improve services. New York, NY: Palgrave Macmillan.

Louer, L. (2013). Political pluralism and governance challenges in Kuwait and Bahrain. In K. Abbas (Ed.), Governance in the Middle East and North Africa: A handbook. Hoboken, NJ: Taylor and Francis.

Luciani, G. (2005). From private sector to national bourgeoisie: Saudi Arabian business. In P. Aarts \& G. Nonneman (Eds.), Saudi Arabia in the balace: Poliical economy, society, foreign affairs. (pp. 144-184). London, UK: Hurst.

Malik, M., \& Niblock, T. (2005). Saudi Arabia's economy: the challenge of reform. In P. Aarts \& G. Nonneman (Eds.), Saudi Arabia in the balance: political economy, society, foreign affairs. (pp. 85-110). London, UK: Hurst.

Makki, Y. (2011). Not what it seems: the role of the tribe in state-society relations in Saudi Arabia. Contemporary Arab Affairs, 4(4), 445-462.

Manning, N. (2001). The legacy of the new public management in developing countries. International Review of Administrative Sciences, 67, 297-312.

Mansour, A. (2007). Public policy and privatization: the case of the Qatari experience. Public Administration and Development, 27(4), 283-292.

Mansour, A. (2008). The impact of privatization on the United Arab Emirates (UAE) Federal public sector.

International public management review, 9(2), 66-87.

McCourt, W. (2008). Public management in developing countries: from downsizing to governance. Public Management Review, 10(4), 467-479.

McKinsey\&Company. (2015). Moving Saudi Arabia's economy beyond oil. McKinsey Global Institute. Retrieved 10 April 2016 from http://www.mckinsey.com/global-themes/employment-and-growth/moving-saudiarabias-economy-beyond-oil

Moore, P. (2002). Rentier fiscal crisis and regime stability: Business-state relations in the Gulf. Studies in Comparative International Development, 37(1), 34-56.

Moore, P. (2004), Doing business in the Middle East: Politics and economic crisis in Jordan and Kuwait. Cambridge, UK: Cambridge University Press.

Nonneman, G. (1988). Development, administration and aid in the Middle East. New York, NY: Routledge.

Osborne, D., \& Gaebler, T. (1992). Reinventing government: How the entrepreneurial spirit is transforming the public sector. Boston, MA: Addison-Wesley.

Oxford Business Group. (2014). The report: Qatar 2014.

Pessoa, A. (2008). public-private partnerships in developing countries: Are infrastructures responding to the new ODA strategy? Journal of international development, 20, 311-325.

Peterson, J. (1977). Tribes and politics in eastern Arabia. Middle East Journal, 31(3), 297-312.

Peterson, J. (1992). Sovereignty and boundaries in the Gulf states. In K. Mehran (Ed.), International Politics of the Persian Gulf (pp. 21-49). Syracuse, NY: Syracuse University Press.

Pierce, J. (2012). Oil and the house of Saud: Analysis of Saudi Arabian oil policy. Digest of Middle East Studies, 21(1), 89-107.

Polidano, C. \& Hulme, D. (1999). Public management refoem in developing countries. Public Management: An International Journal of Research and Theory. 1(1), 121-132.

Pollitt, C. (2015). Towards a new world: Some inconvenient truths for Anglosphere public administration. International Review of Administrative Sciences, 81(1), 3-17.

Pongsiri, N. (2002). Regulation and public-private partnerships. International Journal of Public Sector Management, 15(6), 487-495.

PwC \& the Pearl Initiative. (2013). Family matters - Governance practices in GCC family firms. Retrieved 05 April 2016 from http://www.pwc.com/m1/en/publications/documents/pipwc-report.pdf. 
Qatar News Agency. (2015). Qataris to Occupy 90\% of Public Sector Jobs in 10 Years, HE Minister Says. Retrieved 21 May 2016 from http://www.qna.org.qa/en-us/News/15122616570029/Qataris-to-Occupy-90-of-PublicSector-Jobs-in-10-Years-HE-Minister-Says

Ramady, M. (2010). The Saudi Arabian economy: policies, achievements, and challenges. New York, NY: Springer.

Rathmell, A., \& \& Schulze, K. (2000). Political reform in The Gulf: The case of Qatar. Middle Eastern Studies, 36(4), 47-62.

Sartawi, M. (2012). State owned enterprises in Kuwait: History and recend developments Towards new arrangements for state ownership in the Middle East and North Africa. Paris, FR: OECD Publishing.

Saudi Ministry of Economy and Planning. (2015). Saudi Economic Report 2014.

Segal, E. (2012). Political participation in Kuwait: Diwaniyya, Majlis and Parliament. Journal of Arabian Studies, 2(2), 127-141.

Sharabi, H. (1988). Neopatriarchy: A theory of distorted change in Arab society. Oxford, UK: Oxford University Press.

Smith, K. (1999). Divided government in Kuwait: The politics of parliament since the Gulf war. Digest of Middle East Studies, 8(1), 1-18.

Stack, L. (2011). Seeking to avoid uprising, Kuwait escalates budget. New York Times, June 30.

Segal, E. (2012). Political participation in Kuwait: Diwaniyya, Majlis and Parliament. Journal of Arabian Studies, 2(2), 127-141.

Sharabi, H. (1988). Neopatriarchy: A theory of distorted change in Arab society. Oxford, UK: Oxford University Press.

Smith, K. (1999). Divided government in Kuwait: The politics of parliament since the Gulf war. Digest of Middle East Studies, 8(1), 1-18.

Stack, L. (2011). Seeking to avoid uprising, Kuwait escalates budget. New York Times, June 30.

Tétreault, M. (1995). The Kuwait petroleum corporation and the economics of the new world order. Santa Barbara, CA: Greenwood.

Tétreault, M. (2000). Stories of Democracy: Politics and Society in Contemporary Kuwait New York, NY: Columbia University Press.

The Economist. (2014). Half-opening the gates Foreign businesses are welcome-but only the right sort. Retrieved 11 April 2016 from: http://www.economist.com/news/business/21604176-foreign-businesses-arewelcomebut-only-right-sort-half-opening-gates.

The Economist. (2015a). It will take much cheaper oil for Saudi Arabia to take action. Retrieved December 16,2015

from http://www.economist.com/news/finance-economics/21662570-kingdom-can-stand-more-pain-it-willtake-much-cheaper-oil-saudi-arabia-take-action

The Economist. (2015b). The perils of relying on the sticky stuff. Retrieved 12 June 2016 from http://www.economist.com/news/middle-east-and-africa/21663235-persistent-low-prices-threaten-entireregion-perils-relying.

The National. (2015). Qatar to have its first budget deficit in 15 years. Retrieved 22 May 2016 from http:/www.thenational.ae/business/economy/qatar-to-have-its-first-budget-deficit-in-15-years

The National. (2016). Saudi Arabia has diversified, but economy still depends on oil. Retrieved from: http://www.thenational.ae/business/economy/saudi-arabia-has-diversified-but-economy-still-depends-onoil. Accessed: 12 June 2016

US State Department. (2015). Country Economic Reports. Retrieved 18 May 2016 from http://www.state.gov/r/pa/ei/bgn/5437.htm

WEF. (2015). Retrieved 29 March 2016 from: www.reports.weforum.org/global-competitiveness-report-20152016/economies

World Bank. (2016). World Bank Data Bank: Saudi Arabia. Retrieved 20 May 2016 from data.worldbank.org/ Worthley, J., \& Tsao, K. (1999). Reinvinting government in China: A comparative analysis. Administration and society, $31(5), 571-587$. 
Table 1: Demographic and macro-economic characteristics of Kuwait, Saudi Arabia and Qatar

\begin{tabular}{|c|c|c|c|c|c|c|c|}
\hline States & $\begin{array}{l}\text { Populatio } \\
\mathrm{n} \\
\text { (millions- } \\
2014)\end{array}$ & $\begin{array}{l}\text { Gross } \\
\text { domestic } \\
\text { product } \\
\text { current prices } \\
\text { (billions- } \\
2014 \text { ) }\end{array}$ & $\begin{array}{l}\% \text { of Oil as } \\
\text { share of total } \\
\text { government } \\
\text { budget } \\
\text { revenues } \\
(2015)\end{array}$ & $\begin{array}{l}\text { Oil exports as } \\
\% \text { of } \\
\text { government } \\
\text { earnings } \\
(2015)\end{array}$ & $\begin{array}{l}\text { General } \\
\text { government } \\
\text { expenditure as } \\
\% \text { of GDP } \\
(2014)\end{array}$ & $\begin{array}{l}\% \text { of public } \\
\text { sector } \\
\text { employment } \\
\text { who are } \\
\text { nationals* }\end{array}$ & $\begin{array}{l}\% \text { of private } \\
\text { sector } \\
\text { employment } \\
\text { who are } \\
\text { nationals* }\end{array}$ \\
\hline Kuwait & 3.99 & 171.95 & 89 & 94 & 54.28 & $86.6(2015)$ & $6.4(2015)$ \\
\hline $\begin{array}{l}\text { Saudi } \\
\text { Arabia }\end{array}$ & 30.77 & 753.83 & 80 & 90 & 50.42 & $93.4(2014)$ & $22.1(2014)$ \\
\hline Qatar & 2.23 & 210.10 & 62 & 92 & 35.73 & $84(2012)$ & $9(2012)$ \\
\hline
\end{tabular}

Sources: World Bank (2014, a, b, c); IMF (2014); Forbes (2015, a, b, c); Oxford Business Group (2014); Al-Monitor (2014); Saudi Ministry of Economy and Planning (2015); Kuwait's Central Statistical Bureau (2015)

* (\% of nationals in the public and private sectors do not add up as they represent their share of total employment in each sector)
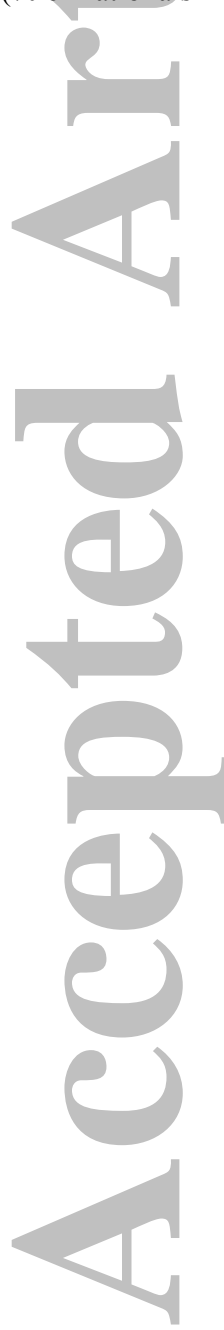
Figure 1: Characteristics and dynamics of the public, private and civil sectors in the three GCC states

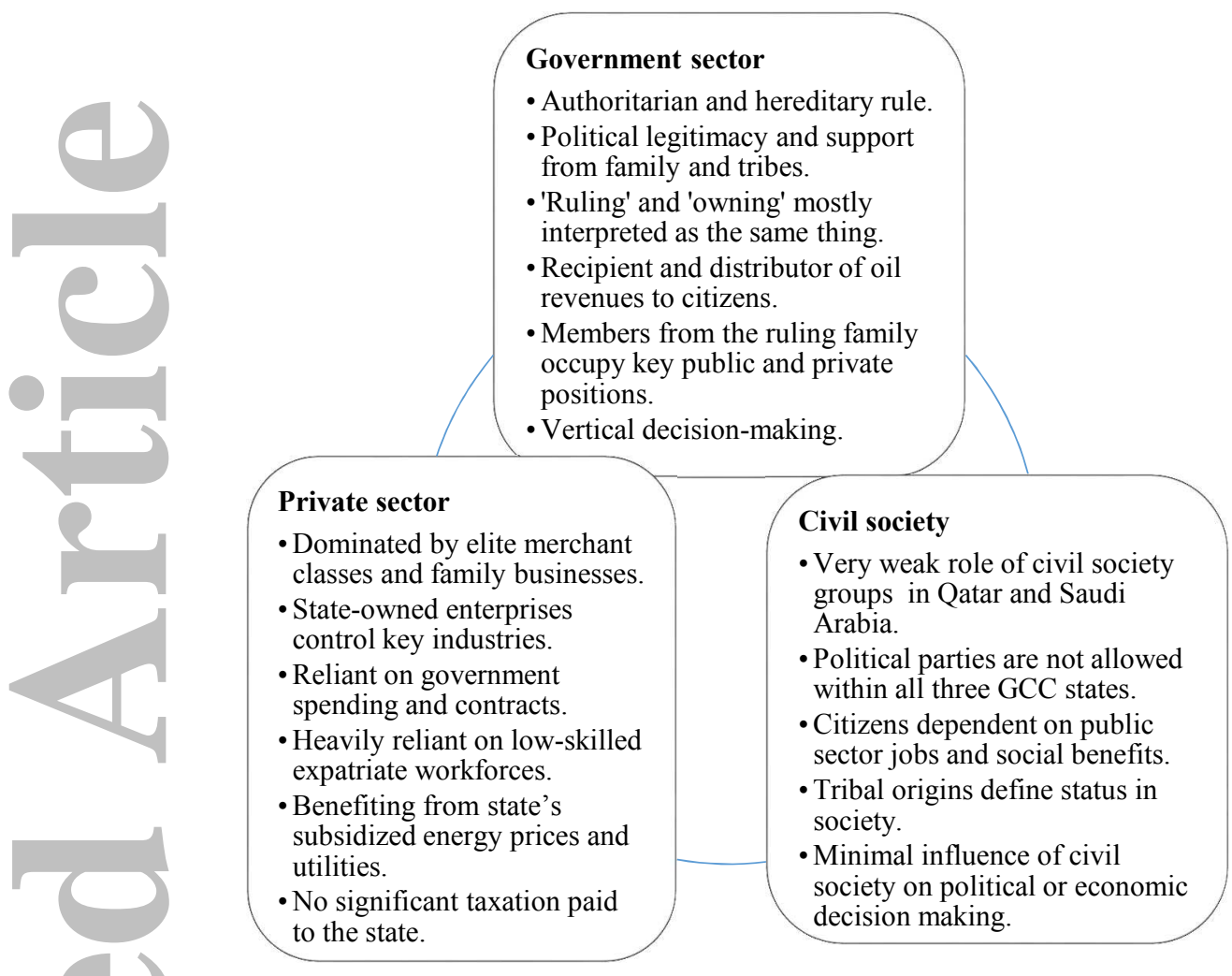

Source: Authors

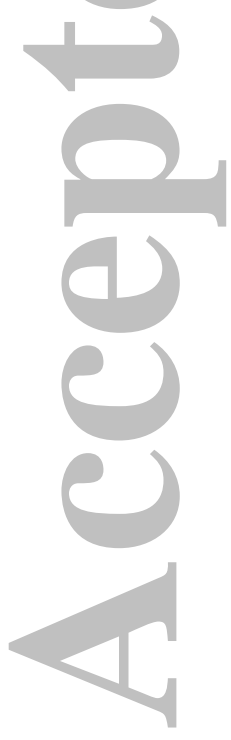




\section{University Library}

\section{- M M N E R VA A gateway to Melbourne's research publications}

Minerva Access is the Institutional Repository of The University of Melbourne

Author/s:

Biygautane, M;Gerber, P;Hodge, G

Title:

The Evolution of Administrative Systems in Kuwait, Saudi Arabia, and Qatar: The Challenge of Implementing Market Based Reforms

Date:

2016

Citation:

Biygautane, M., Gerber, P. \& Hodge, G. (2016). The Evolution of Administrative Systems in Kuwait, Saudi Arabia, and Qatar: The Challenge of Implementing Market Based Reforms.

Digest of Middle East Studies, 26 (1), pp.97-126. https://doi.org/10.1111/dome.12093.

Persistent Link:

http://hdl.handle.net/11343/290785 